\title{
Characteristics of Central American brocket deer resting sites in a tropical mountain cloud forest in eastern Mexico
}

\author{
Brenda Muñoz Vazquez ${ }^{1,2}$, Sonia Gallina Tessaro ${ }^{3}$, Livia León-Paniagua ${ }^{\text {Corresp. } 1}$ \\ ${ }^{1}$ Museo de Zoología "Alfonso L. Herrera”, Departamento de Biología Evolutiva, Facultad de Ciencias, Universidad Nacional Autónoma de México, Mexico \\ city, Mexico city, Mexico \\ 2 Posgrado en Ciencias Biológicas edificio D, 1ㅇ Piso. Circuito de Posgrados, Ciudad Universitaria Del. Coyoacan. C. P. 04510, Universidad Nacional \\ Autónoma de México, Ciudad de México, México \\ 3 Red de Biología y Conservación de Vertebrados, Instituto de Ecología, A.C, Xalapa, Mexico \\ Corresponding Author: Livia León-Paniagua \\ Email address: Ilp@ciencias.unam.mx
}

The Central American brocket deer is a vulnerable species. Geographically isolated populations have been affected by poaching and habitat fragmentation, leading to local extinctions. It is therefore important to understand this species' habitat characteristics, particularly of resting sites, which play a crucial role in survival and fitness. We describe the characteristics and distribution patterns of Central American brocket deer resting sites at the microhabitat and landscape scales in San Bartolo Tutotepec, Hidalgo, México. We conducted eight bimonthly field surveys between November 2017 and March 2019, consisting of 32 transects of $500 \mathrm{~m}$ length to search for fecal pellets, footprints, scrapes, and browsed plants. At each resting site we identified, we measured canopy closure, horizontal thermal cover, protection from predators for fawns and adults, escape routes, slope from the ground, presence of scrapes, cumulative importance value of the edible plant species, and distance from the resting site to the nearest water resource to characterize the site at the microhabitat scale. At the landscape scale, we identified the type of biotope, elevation, aspect, and slope. We compared all of these parameters from resting sites with a paired randomly selected site to serve as a control. We performed a multiple logistic regression to identify the parameters associated with the resting sites and a point pattern analysis to describe their distribution. We characterized 43 resting sites and their corresponding control plots. At the microhabitat scale, resting sites were associated with higher vertical thermal cover, more concealment cover, more escape routes, more edible plant species, higher slope from the ground, and closer distance to water resources. At the landscape scale, resting sites were associated with beech forest, oak forest, secondary forest, and ravine biotopes and negatively associated with pine forest, houses, and roads. Resting sites had an aggregated spatial pattern from 0 to 900 $\mathrm{m}$, but their distribution was completely random at larger scales. Our study revealed that 
Central American brocket deer selected places with specific characteristics to rest, at both microhabitat and landscape scales. We, therefore, suggest that existing habitat be increased by reforesting with native species-particularly Mexican beech forest and oak forest-to improve the deer's conservation status in the study area. 
1 Brenda Muñoz-Vazquez ${ }^{1,2}$, Sonia Gallina ${ }^{3}$, Livia León-Paniagua ${ }^{1 *}$

2 Characteristics of Central American brocket deer resting sites in a mountain cloud forest in eastern Mexico

4 1Museo de Zoología “Alfonso L. Herrera”, Departamento de Biología Evolutiva, Facultad de

5 Ciencias, Universidad Nacional Autónoma de México. Avenida Universidad 3000, CP. 04510,

6 Mexico City, Mexico.

$7 \quad$ 2Posgrado en Ciencias Biológicas, edificio D, $1^{\text {o }}$ Piso. Circuito de Posgrados, Ciudad

8 Universitaria Del. Coyoacan. C. P. 04510, Ciudad de México, Mexico.

$9{ }^{3}$ Red de Biología y Conservación de Vertebrados, Instituto de Ecología, A.C., Carretera Antigua

10 a Coatepec \#351, El Haya, 91073 Xalapa, Veracruz, México.

11 Abstract

12 The Central American brocket deer is a vulnerable species. Geographically isolated populations have been affected by poaching and habitat fragmentation, leading to local extinctions. It is therefore important to understand this species' habitat characteristics, particularly of resting sites, which play a crucial role in survival and fitness. We describe the characteristics and distribution patterns of Central American brocket deer resting sites at the microhabitat and landscape scales

17 in San Bartolo Tutotepec, Hidalgo, México. We conducted eight bimonthly field surveys between November 2017 and March 2019, consisting of 32 transects of $500 \mathrm{~m}$ length to search for fecal pellets, footprints, scrapes, and browsed plants. At each resting site we identified, we measured canopy closure, horizontal thermal cover, protection from predators for fawns and

21 adults, escape routes, slope from the ground, presence of scrapes, cumulative importance value of the edible plant species, and distance from the resting site to the nearest water resource to characterize the site at the microhabitat scale. At the landscape scale, we identified the type of biotope, elevation, aspect, and slope. We compared all of these parameters from resting sites 
with a paired randomly selected site to serve as a control. We performed a multiple logistic regression to identify the parameters associated with the resting sites and a point pattern analysis to describe their distribution. We characterized 43 resting sites and their corresponding control plots. At the microhabitat scale, resting sites were associated with higher vertical thermal cover, more concealment cover, more escape routes, more edible plant species, higher slope from the ground, and closer distance to water resources. At the landscape scale, resting sites were associated with beech forest, oak forest, secondary forest, and ravine biotopes and negatively associated with pine forest, houses, and roads. Resting sites had an aggregated spatial pattern from 0 to $900 \mathrm{~m}$, but their distribution was completely random at larger scales. Our study revealed that Central American brocket deer selected places with specific characteristics to rest, at both microhabitat and landscape scales. We, therefore, suggest that existing habitat be increased by reforesting with native species — particularly Mexican beech forest and oak forestto improve the deer's conservation status in the study area.

\section{Introduction}

The Central American brocket deer is a vulnerable species, with geographically isolated populations mainly found in mountain cloud forests and evergreen forests (Gallina-Tessaro et al., 2019). The species is currently facing conservation problems due to overexploitation and the loss and fragmentation of its habitats (Muñoz Vazquez \& Gallina Tessaro, 2016). In addition to the current scenario, projections of future habitat transformation are not favorable for the species, making it critical to understand its habitat characteristics, particularly of its resting sites, which play a crucial role in maintaining the species (Cuarón, 2000; Acosta, 2011; Findlay et al., 2015). 
47 Resting sites have important effects on survival and fitness; they provide adults and offspring with

48 protection from predators, thermal cover, comfort, and access to food and water resources

49 (Lutermann, Verburgt \& Rendigs, 2010; Li, Li \& Liu, 2017).

50 Resting sites allow an animal to hide from predators during inactive periods and breeding and get

51 access to escape routes, in order to reduce predation risk. This is particularly important for prey

52 species such as Central American brocket deer that is the most important prey for cougar (Puma

53 concolor), an essential part of the diet of jaguar (Panthera onca) and an occasional prey of tayras

54 (Eira Barbara; Foster et al., 2010; Mello et al., 2021). Domestic dogs (Canis lupus familiaris) also

55 attack and kill Central American brocket deer (Muñoz-Vazquez, 2013).

56 Resting sites also provide thermal cover, defined as coniferous or deciduous overstories and or

57 plant understories that protect an animal from microclimatic extremes of heat and radiation mainly

58 during solar noon. This protection decreases the metabolic costs related to heat dissipation, as well

59 as providing shelter from rain and blocking wind, buffering against variation in temperature and

60 moisture (Demarchi \& Bunnell, 1993).

61 As well as security, resting sites must offer comfort to an animal to assure its well-being (Erdtmann

$62 \&$ Keuling, 2020). Comfort behaviors include the selection of the resting surface. For instance,

63 some deer species that inhabit clay-eroded ravine landscapes select a flat spot so that they do not

64 slide off the resting site, which they scrape by pawing the soil and remove branches so the resting

65 site itself becomes more concave (Mysterud \& Ostbye, 1995).

66 Access to food and water sources are also potentially important aspects of resting site habitat. It

67 has been observed that most territories contain patches of high-quality food that limits deer

68 distribution (Carranza, FernandezLlario \& Gomendio, 1996). The diet of the Central American 
69 brocket deer varies among regions and ecosystems; in the tropics it behaves like a specialist

70 frugivore, while in the mountain cloud forests it behaves like a browser with a broader 71 consumption spectrum (Weber, 2005; Villarreal-Espino-Barros et al., 2008; Flores-Vazquez, 72 2021). Access to water resources, on the other hand, is important even in places where water is not

73 limited (e.g., in mountain cloud forests, which retain moisture nearly year-round due to horizontal 74 rain). For instance, some large herbivores that inhabit this ecosystem locate their resting sites near 75 to some ponds that contained water all year for cooling off during the hottest hours of the day (de 76 la Torre et al., 2018).

77 Research on the Central American brocket deer has primarily considered their spatial distribution 78 and basic ecology, leaving the habitat requirements for resting sites virtually unknown (Weber, 79 2005; Muñoz Vazquez \& Gallina Tessaro, 2016). Here, we describe the characteristics of Central American brocket deer resting sites. We did this at two different scales: microhabitat and landscape (Johnson, 1980). We hypothesized that the distribution and structure of resting sites would be driven by variables related to thermal cover, protection from predators, comfort, access to food and water resources and habitat preferences. We predicted that Central American brocket deer resting sites would follow an aggregated pattern and that they would have some specific characteristics. At the microhabitat scale, we expected greater thermal and hiding cover, flatter surfaces and more comfort behavior signs, more edible plant species, and shorter distance to water in resting sites compared to randomly selected control sites. At the landscape scale, we predicted (based on Central American brocket deer and other deer species habitat preferences) that resting sites would be most frequent in beech forests, at elevations above $1500 \mathrm{~m}$, with flat or almost flat slopes and with hillsides oriented to the north. 


\section{Material and Methods}

93 Study area

94 The study was carried out in the mountain cloud forest of San Bartolo Tutotepec, which spans over 6070.1 ha in eastern Hidalgo, Mexico (UTM 572661 2261171, 582857 2261149, 572639 2255120, 582880 2255098; Fig. 1). The forest forms part of the priority region "Mountain cloud forests of the Sierra Madre Oriental" and the Ecoregion "Montane Forests of Veracruz" (CONABIO, 2010). The climate is temperate and humid with two seasonal periods throughout the year: a dry season from October to May and a rainy season from June to September (Peters, 1997). The annual rainfall is 1200 to $2000 \mathrm{~mm}$, and the average temperature is approximately 12

${ }^{\circ} \mathrm{C}$ to $18{ }^{\circ} \mathrm{C}$. It ranges in elevation from 200 to $1944 \mathrm{~m}$ and has a rugged topography, with steep slopes where rivers and streams run between the pronounced ravines, emptying into the river Chiflón (CONAGUA, 2012). The hilly countryside is covered by tropical mountain cloud forest fragmented by agricultural lands and pastures. It contains relict-endemic and endangered tree species such as Magnolia schiedeana, Fagus grandifolia subsp. mexicana, Quercus delgadoana,

Q. trinitatis, Q. meavei, Symplocos coccinea, Styrax glabrescens, Turpinia insignis, Persea spp.

Several tree fern species, including Cyathea fulva, Dicksonia sellowiana var. arachneosa and Alsophila firma, inhabit steep slopes. The understory is mainly composed of Miconia glaberrima. Central American brocket deer share habitat with other mammals such as coyote

110 (Canis latrans), gray fox (Urocyon cinereoargenteus), jaguarundi (Puma yagouaroundi), ocelot 111 (Leopardus pardalis), margay (Leopardus wiedii), American hog-nosed skunk (Conepatus

112 leuconotus), hooded skunk (Mephitis macroura), long-tailed weasel (Mustela frenata), ringtails 113 (Bassariscus astutus), white-nosed coati (Nasua narica), kinkajou (Potos flavus), raccoon 114 (Procyon lotor), nine-banded armadillo (Dasypus novemcinctus), Eastern cottontails (Sylvilagus 
115 floridanus), lowland paca (Cuniculus paca) and Mexican red-bellied squirrel (Sciurus

116 aureogaster) among others (Huerta-Valdez, 2017). It is important to mention that until recently it

117 was thought that its natural predator, the cougar (Puma concolor), had been extirpated from the

118 area, but recent observations confirm its presence (A. Cruz-Oropeza, 2021, unpublished data).

119 The study area has been occupied by humans since the 10th century, when the Toltec civilization

120 inhabited the area. Currently there are 12 Otomí communities in the region, ranging from 40 to

121258 inhabitants, whose main economic activities are agriculture and extensive livestock

122 production (Muñoz-Vazquez, 2013).

\section{Resting site attributes}

124 We conducted eight bimonthly field surveys between November 2017 and March 2019 with four

125 transects per field season (32 in total). Each transect was $500 \mathrm{~m}$ long and were distributed

126 uniformly within the part of the study area that is suitable for brocket deer, according to Muñoz

127 Vazquez \& Gallina Tessaro (2016); i.e., avoiding human settlements, pastures and crops. The

128 starting points of the transects were randomly selected a priori and the direction was always

129 north-south. The minimum distance between transects was $200 \mathrm{~m}$ in order to cover as much

130 habitat as possible. Each every transect was visited once by four people who directly searched

131 for resting sites (Fig. 2).

132 We identified resting sites based on the presence of fecal pellets following Aranda (2012), which

133 sometimes formed latrines. We also searched for footprints, scrapes (soil disturbed by deer

134 pawing at the ground), and browsed plants (Fig. 3). Whenever we observed a resting site, we

135 recorded its coordinates using a GPS. 
136 To describe the resting site, we assessed habitat characteristics at two different spatial scales: the

137 microhabitat (specific surface that was used for resting and the $20 \mathrm{~m}^{2}$ surrounding the resting

138 site) and the landscape (the $30 \mathrm{~m}^{2}$ surrounding the resting site).

\section{Microhabitat}

140 Resting sites were characterized by recording vertical and horizontal thermal cover, protection

141 from predators for fawns and adults, comfort signs, and availability of food and water. First, we

142 performed 20 readings of canopy closure (five in each of the four cardinal directions) between

143 9:00 am and 12:00 pm using a densiometer to estimate vertical thermal cover (Model C,

144 Lemmon, 1957, Fig. 3C). Second, we followed the Canfield method along four $10 \mathrm{~m}$-long

145 transects (beginning at the resting site and progressing in each cardinal direction), to record all

146 understory vegetation cover $\leq 2 \mathrm{~m}$ in height. These surveys were used to calculate the understory

147 density and coverage height as measures of horizontal thermal cover (see Canfield, 1941).

148 We measured concealment cover following Griffith \& Youtie (1988) at $10 \mathrm{~m}$ from the resting

149 site; the only modification was that we considered the cover closest to the ground ("first

150 segment", 0-50 cm) as protection from predators for fawns and the cover in the second (50-100

$151 \mathrm{~cm})$ and third segments $(100-150 \mathrm{~cm})$ as protection from predators for adults (Fig. 3B). We also

152 counted deer footpaths using a manual counter (Base Mount Tally Counter), which we

153 considered the potential escape routes from predators.

154 As comfort signs, we measured the slope from the ground by using a clinometer (SUUNTO), and

155 we registered the presence/absence of scrapes and the tree and/or tree fern species under which

156 the site was located to determine whether there was a preference for a particular species of

157 tree/tree fern for resting sites. 
158 To evaluate food availability, we identified the plant species along the transect and compared to

159 the to the lists of plant species consumed by deer compiled by Villarreal-Espino-Barros et al.

160 (2008) and Flores-Vazquez (2021) and calculated the cumulative importance value of the edible

161 plant species with the following formulas:

162

$$
\text { v.i. } \text { acum }=\text { v.i. } s p_{1}+\text { v.i. } s p_{2}+\ldots+\text { v.i. } s p_{n}
$$

163

$$
v_{. i} ._{\text {edible species }}=\text { understory density }+ \text { understory coverage }+ \text { frequency }
$$

164 Finally, to record access to water, we measured the linear distance from the resting site to the 165 nearest water source (e.g., permanent and ephemeral ponds, creeks), using a measuring tape (Fig. $1663)$.

\section{Landscape}

168 Since we hypothesized that the habitat preferences of the Central American brocket deer influenced the selection of its resting sites, we used four landscape-scale variables to describe resting sites. Type of biotope was derived from a Landsat 8 OLI image, using an Iso cluster function with unsupervised classification to obtain a biotope type layer that was categorized into

172 the following discrete classes: beech forest, oak forest, secondary vegetation, pine forest, 173 rainforest, ravines, houses and roads, and grazing areas (areas devoid of native vegetation and 174 dedicated to livestock grazing). Elevation was derived directly from a digital elevation model 175 (DEM), and aspect and slope that were calculated with the Surface toolbox in Arc Map 10.3

176 from the DEM. Erdas Imagine software v.14.0 was used to reproject the Landsat and DEM 177 images and to perform atmospheric and radiometric corrections (Intergraph Corporation). Pixel 178 size for both images was $30 \mathrm{~m}^{2}$. 
179 For each resting site surveyed, we established a paired control plot where we measured the same 180 microhabitat and landscape attributes. Control plots were selected by measuring at the point 50

$181 \mathrm{~m}$ from the identified resting site in a randomly selected cardinal direction.

\section{Statistical analyses}

183 We first tested whether the explanatory variables were normally distributed. Spearman rank tests 184 were used to evaluate correlations $\left(\mathrm{r}_{\mathrm{s}} \geq|0.7|\right)$. Then, multiple logistic regressions were used to 185 differentiate combinations of variables associated with the resting sites. We chose this analysis 186 because multiple logistic regressions are especially useful when the data consist of both discrete 187 and continuous variables (Powell, 2000).

188

\section{Resting site distribution}

We used a point pattern analysis to describe resting site distribution. First, we used the resting site locations to construct a planar point pattern (ppp), then used the Kernel-smoothed intensity to measure the mean number of occurrences per unit at a point $(u)$ defined by $\lambda(u)$. Finally, we performed first-order characteristics analysis of a spatial process for a general location $(s$; Equation 1):

$\lambda_{b}(s)=\frac{1}{C_{b}(s)} \sum_{i=1}^{n} K_{i b}\left(s-x_{i}\right) \quad$ Equation 1 where $\mathrm{K}_{\mathrm{b}}\left(\right.$ ) is a Kernel with band $\mathrm{b}>0$, and $\mathrm{C}_{\mathrm{b}}(\mathrm{)}$ ) is an edge correction factor (Yang et al., 2007).

We performed a quadrat count test to determine whether there was complete spatial randomness. Once we determined that the pattern was not random, we calculated the inhomogeneous $\mathrm{K}$ and $\mathrm{L}$ functions (Equation 2): 


$$
\hat{K}_{\text {inhom }}(r)=\frac{1}{|W|} \sum_{i} \sum_{j \neq i} \frac{1\left\{\left\|x_{i}-x_{j}\right\| \leq r\right\}}{\hat{\lambda}\left(x_{i}\right) \hat{\lambda}\left(x_{j}\right)} e\left(x_{i}, x_{j} ; r\right) \text { Equation } 2
$$

201 Where $e(u, v, r)$ is an edge correction weight and $\hat{\lambda}(u)$ is an estimate of the intensity function $202 \lambda(u)$.

\section{Results}

205

206

We found and characterized 43 resting sites and their corresponding control plots. It is important to note that this is the first time that latrine formation is reported for Central American brocket deer. At the microhabitat scale, we observed that the probability of being a resting site in the area was positively associated with vertical thermal cover, concealment cover, the number of escape routes and the presence of edible plant species and negatively associated with the distance to water resources. Resting sites were found on flat and nearly flat surfaces, and scrapes were only recorded at resting sites (Table 1).

At the landscape scale, we observed that the probability of being a resting site was positively associated with beech forest, oak forest, secondary forest and ravine biotopes and negatively associated with pine forest, houses and roads and grazing area biotopes (Table 1).

The highest density of resting sites occurred in two "hotspots" located at the center of the study area (Fig. 4). K and L function graphs showed that the empirical curve was higher than the theoretical curve at distances up to $900 \mathrm{~m}$ (Fig. 5). Therefore, we determined that the resting sites had an aggregated spatial pattern from 0 to $900 \mathrm{~m}$, while their distribution was completely random at larger scales. 


\section{Discussion}

221 Our results support the idea that resting sites are important places for Central American brocket

222 deer, since they provide adults and offspring with thermal cover, protection from predators,

223 comfort, and access to food and water resources. Central American brocket deer selected resting

224 site locations with high canopy closure, probably seeking protection from extreme heat and

225 radiation during solar noon and from the rain and excess moisture in the extremely rainy

226 environment of the mountain cloud forest (Demarchi \& Bunnell, 1993).

227 Our results also showed the importance of concealment cover and the presence of escape routes,

228 suggesting that landscapes that offer more protection contribute to the avoidance of predators.

229 This trend has also been reported for other deer species, such as fawn and adults of white-tailed

230 deer (Huegel, Dahlgren \& Gladfelter, 1986; Gallina et al., 2010). In our study area, we detected

231 the presence of the main natural predator of Central American brocket deer, Puma concolor, and

232 of free-ranging and feral dogs that can also act as predators (Foster et al., 2010; Huerta-Valdez,

233 2017; Christen, Janko \& Rehnus, 2018).

234 Not surprisingly, deer chose resting sites located closer to streams and rills than expected at

235 random. Central American brocket deer have an affinity for water bodies. The species was

236 originally named temamazame, which means "deer that likes water," by Hernandez in his

237 expedition to Nueva España during 1571-1574 (Hernandez, 1651). Also, deer were recorded

238 swimming across the Lacantun river during the dry season when the waters were shallow

239 (Naranjo \& Bodmer, 2007). It is very likely that deer use the water bodies for cooling off during

240 the hottest hours of the day and to prevent ectoparasites (de la Torre et al., 2018; Delgado-

241 Martínez et al., 2018; Lira et al., 2018). This behavior coincides with that observed in red

242 brocket deer in the Chiquitano forest of Bolivia, where the species preferred riverine forests 
243 where water was available year-round to other habitats where ponds and running streams are

244 present only during the rainy season (Rivero, Rumiz \& Taber, 2005).

245 Central American brocket deer also prefer flat spots $\left(\approx 180^{\circ}\right)$ to rest, and the presence of scrapes

246 by pawing the soil were common. This was despite the fact that resting sites were located in

247 areas where the overall terrain was steep; this suggests that they chose locally flat sites to avoid

248 sliding off of the resting site, which could be interpreted as a comfort sign (Erdtmann \& Keuling,

249 2020). It has been observed in other deer species that beds occupied over the longer term are

250 more frequently scraped than beds used for a short time, and scraping behavior may also function

251 in olfactory communication (Mysterud \& Ostbye, 1995; Black-Decima \& Santana, 2011, Hearst et

252 al., 2021).

253 Our results showed that biotope was the most important variable in resting site distribution.

254 Similarly, Garcia-Marmolejo et al. (2013) found that landscape composition was the single most

255 important variable contributing to potential distribution of $M$. temama in the Huasteca region of

256 San Luis Potosí, Mexico. Despite the availability of different biotopes, a relatively high

257 percentage of resting sites were found in Mexican beech forest habitats. Remnants of Mexican

258 beech forest are considered hotspots with high connectivity and low disturbance in our study area

259 (Rodríguez-Ramírez, Sánchez-González \& Ángeles-Pérez, 2016). Additionally, secondary

260 vegetation clearly played an important role in resting sites, coinciding with other studies where

261 deer are distributed in secondary vegetation near well-preserved forests (Bello-Gutiérrez,

262 Guzmán-Aguirre \& Chablé-Montero, 2004). Ravines were also important sites for Central

263 American brocket deer resting sites, in our study area ravines, locally known as "jewels" are

264 places where the mountains come together and create high humidity microhabitats that favor the

265 presence of dense vegetation, as well as steep and sloping terrain, which generates good hiding 
266 places for the deer and are sometimes used as safe trails from potential predators such as cougar

267 (Puma concolor) or dogs. Other mammals, such as the common genet (Genetta genetta) in the

268 Mediterranean, have been shown to use ravines similarly as safe passages and resting site

269 locations (Camps, 2011).

270 Regarding the distribution of resting sites, we found that Central American brocket deer were

271 selective. Resting sites were only found in the center of the study area, in accordance with results

272 across southeastern Mexico that show that the species restricts its distribution to areas far from

273 the forest edges, with only occasional excursions to edge habitats. Thus, the current study

274 supports previous findings showing that Central American brocket deer may be considered a

275 habitat specialist (Bello-Gutiérrez, Guzmán-Aguirre \& Chablé-Montero, 2004; Weber, 2005 , 276 2008).

\section{Conclusions}

279 Our study revealed that Central American brocket deer select places with specific characteristics to rest, at both the microhabitat and landscape scales. The most important parameters at the microhabitat scale were food and water availability, vertical thermal cover, concealment cover, and slope from the ground, while at the landscape scale the most important variables were the type of biotope (positively associated with beech forest, oak forest, secondary vegetation and ravines, and negatively associated with houses and roads and grazing areas). In our study area, there are only a few forest patches that meet Central American brocket deer resting site requirements; most of the habitat is unsuitable for this behavior due to disturbance, including

287 intense agricultural and livestock activity. This scenario has been observed in most of the studies 
288 of this species, and Central American brocket deer habitat is frequently highly fragmented.

289 Therefore, we recommend increasing the existing habitat by reforesting with native species, 290 especially in Mexican beech forest and oak forest, to improve the species' conservation status in 291 the area.

\section{Acknowledgments}

293 We are grateful to Emiliano Donadio, Patricia Black Decima and one anonymous reviewer for improving 294 the manuscript. This paper constitutes part of the doctoral research of BMV, who thanks the graduate 295 program Doctorado en Ciencias Biológicas, UNAM and acknowledges the scholarship provided by 296 CONACyT. BMV gratefully acknowledges E. Chanes for his support in every aspect of this project.

\section{References}

298

Acosta G. 2011. El Poblamiento De Las Regiones Tropicales. An. Antrop 45:227-235.

Aranda JM. 2012. Manual para el rastreo de mamiferos silvestres de México. México, D.F: Comisión Nacional para el Conocimiento y Uso de la Biodiversidad (Conabio). DOI: 10.5962/bhl.title.113211.

Bello-Gutiérrez J, Guzmán-Aguirre C, Chablé-Montero C. 2004. Caracterización del hábitat de tres especies de artiodáctilos en un área fragmentada de Tabasco México. VI Congreso Internacional sobre Manejo de Fauna silvestre en la Amazonia y Latinoamérica:136-145.

Black-Decima P, Santana M. 2011. Olfactory communication and counter-marking in brown brocket deer Mazama gouazoubira. Acta Theriologica 56:179-187. DOI: 10.1007/s13364-010-0017-6.

Canfield RH. 1941. Application of the line interception method in sampling range vegetation. J. Forest. 39:388-394.

Carranza J, FernandezLlario P, Gomendio M. 1996. Correlates of territoriality in rutting red deer. Ethology 102:793-805. DOI: 10.1111/j.1439-0310.1996.tb01201.x. 
310 Christen N, Janko C, Rehnus M. 2018. The effect of environmental gradients on the bed site selection of 311 roe deer (Capreolus capreolus). Mammal Research 63:83-89. DOI: 10.1007/s13364-017-0343-z.

312 CONABIO. 2010. El Bosque Mesófilo de Montaña en México: Amenazas y Oportunidades para su

313 Conservacion y Manejo Sostenible. México, D. F, México: Comisión Nacional para el

314 Conocimiento y Uso de la Biodiversidad.

315 CONAGUA. 2012.Consejo de cuenca de los ríos Tuxpan al Jamapa. Available at http://smn.cna.gob.mx 316 (accessed February 20, 2009).

317 Cuarón AD. 2000. Effects of Land-Cover Changes on Mammals in a Neotropical Region : a Modeling $318 \quad$ Approach. 14:1676-1692.

319

320

321

322

323

324

325

326

327

328

329

330

331

332

Delgado-Martínez CM, Alvarado F, Mendoza E, Flores-Hernández S, Navarrete A, Navarrete E, Botello F. 2018. An ignored role of sartenejas to mitigate water shortage hazards for tropical forest vertebrates. Ecology 99:758-760. DOI: 10.1002/ecy.2078.

Demarchi MW, Bunnell FL. 1993. Estimating forest canopy effects on summer thermal cover the Cervidae (deer family). Canadian Journal of Forest Research 23:2419-2426. DOI: 10.1139/x93299.

Erdtmann D, Keuling O. 2020. Behavioural patterns of free roaming wild boar in a spatiotemporal context. PeerJ 8. DOI: 10.7717/peerj.10409.

Findlay MA, Robert AB, Diamond, Neil, White PJC. 2015. Developing an empirical approach to optimal camera-trap deployment at mammal resting sites: evidence from a longitudinal study of an otter Lutra lutra holt. Journal of wetlands research 17:1-10.

Flores-Vazquez RJ. 2021. Hábitos alimenticios del venado temazate rojo (Mazama temama), en San Bartolo Tutotepec. Biol. Thesis.Universidad Nacional Autónoma de México.

Foster RJ, Harmsen BJ, Valdes B, Pomilla C, Doncaster CP. 2010. Food habits of sympatric jaguars and 
pumas across a gradient of human disturbance. Journal of Zoology 280:309-318. DOI: 10.1111/j.1744-7429.2010.00641.x.

335

Gallina-Tessaro S, Pérez-Solano LA, Reyna-Hurtado R, Escobedo-Morales LA. 2019. Brocket Deer. In: Ecology and Conservation of Tropical Ungulates in Latin America. 395-414. DOI: 10.1007/978-3030-28868-6.

Gallina S, Bello J, Verteramo CC, Delfin C. 2010. Daytime bedsite selection by the texan white-tailed deer in xerophyllous brushland, North-eastern Mexico. Journal of Arid Environments 74:373-377. DOI: 10.1016/j.jaridenv.2009.09.032.

Garcia-Marmolejo G, Chapa-Vargas L, Huber-Sannwald E, Weber M, Rosas-Rosas OC, MartinezCarderas J. 2013. Potential distributional patterns of three wild ungulate species in a fragmented tropical region of northeastern Mexico. Tropical Conservation Science 6:539-557.

Griffith B, Youtie BA. 1988. Two Devices for Estimating Foliage Density and Deer Hiding Cover. Wildlife Society Bulletin 16:206-210.

Hearst S, Streeter S, Hannah J, Taylor G, Shepherd S, Winn B, Mao J. 2021. Scraping Network Analysis: A Method to Explore Complex White-Tailed Deer Mating Systems. Southeastern Naturalist 20:192-211. DOI: 10.1656/058.020.0122.

Hernandez F. 1651. De los MAZAME o ciervos. In: Historia Natural de la Nueva España 2. Tratado Primero. 325.

Huegel CN, Dahlgren RB, Gladfelter HL. 1986. Bedsite Selection by White-Tailed Deer Fawns in Iowa. Journal of Wildlife Management 50:474-480.

Huerta-Valdez S. 2017. Los mamíferos de San Bartolo Tutotepec, Hidalgo, México. Biol. Thesis, Universidad Autónoma del Estado de Hidalgo.

Johnson DH. 1980. The Comparison of Usage and Availability Measurements for Evaluating Resource 
Preference. Ecology 61:65-71. DOI: 10.1007/s12630-014-0147-4.

357

358

359

360

361

362

363

364

365

366

367

368

369

370

371

372

373

374

375

376

377

378

Kirby RB, Muller LI, Chamberlain MJ, Conner M. 2017. Hardwood management and restoration of longleaf pine ecosystems may affect raccoon daytime resting sites. Restoration Ecology 25:424431. DOI: $10.1111 /$ rec.12455.

de la Torre JA, Rivero M, Camacho G, Álvarez-Márquez LA. 2018. Assessing occupancy and habitat connectivity for Baird's tapir to establish conservation priorities in the Sierra Madre de Chiapas, Mexico. Journal for Nature Conservation 41:16-25. DOI: 10.1016/j.jnc.2017.10.004.

Lemmon PE. 1957. A New Instrument for Measuring Forest Overstory Density. Journal of Forestry 55:667-668.

Li J, Li YK, Liu WH. 2017. Autumn bed site selection by sika deer (Cervus nippon) in the Taohongling National Nature Reserve, China. Russian Journal of Ecology 48:384-391. DOI: $10.1134 / \mathrm{s} 1067413617040105$.

Lira PK, Pires ADS, Carlos HSA, Curzio PDL, Fernandez FADS. 2018. Resting sites of opossums (Didelphimorphia, Didelphidae) in Atlantic Forest fragments. Mammalia 82:62-64. DOI: 10.1515/mammalia-2016-0098.

Lutermann H, Verburgt L, Rendigs A. 2010. Resting and nesting in a small mammal: Sleeping sites as a limiting resource for female grey mouse lemurs. Animal Behaviour 79:1211-1219. DOI: 10.1016/j.anbehav.2010.02.017.

Mello MCH, Mello RC, Grotta-neto F, Bernardi P, Carrano E, Passos FC. 2021. Natural History Notes The role of tayra (Eira barbara) as predator of medium and large-sized mammals. Austral Ecology 46:329-333. DOI: 10.1111/aec.12982.

Muñoz-Vazquez B. 2013. Distribución, abundancia y uso de hábitat del venado temazate (Mazama temama) en los bosques mesófilos de San Bartolo, Tutotepec, Hidalgo, México. MSc Thesis, 
Instituto de Ecología, A. C.

Muñoz Vazquez B, Gallina Tessaro S. 2016. Influence of habitat fragmentation on abundance of Mazama temama at different scales in the cloud forest. Therya 7:77-87. DOI: 10.12933/therya-16-338.

Mysterud A, Ostbye E. 1995. Bed-site selection by adult roe deer Capreolus capreolus in southern Norway during summer. Wildlife Biology 2:101-106. DOI: 10.2981/wlb.1996.038.

Naranjo EJ, Bodmer RE. 2007. Source-sink systems and conservation of hunted ungulates in the Lacandon Forest, Mexico. Biological Conservation 138:412-420. DOI: 10.1016/j.biocon.2007.05.010.

Peters R. 1997. Beech Forests. The Netherlands: Springer Science+Business Media Dordrecht. DOI: 10.1007/978-94-015-8794-5.

Powell RA. 2000. Animal Home Ranges and Territories and Home Range Estimators. In: Boitani L, Fuller TK eds. Research Techniques in Animal Ecology. New York: Columbia University Press, 65110.

Rivero K, Rumiz DI, Taber AB. 2005. Differential habitat use by two sympatric brocket deer species (Mazama americana and M. gouazoubira) in a seasonal Chiquitano forest of Bolivia. Mammalia 69:169-183. DOI: 10.1515/mamm.2005.015.

Rodríguez-Ramírez EC, Sánchez-González A, Ángeles-Pérez G. 2016. Relationship between vegetation structure and microenvironment in Fagus grandifolia subsp. mexicana forest relicts in Mexico. Journal of Plant Ecology 11:237-247. DOI: 10.1093/jpe/rtw138.

Stopher K V, Walling CA, Morris A, Guinness FE, Clutton-brock TH, Pemberton JM, Nussey DH. 2012. Shared spatial effects on quantitative genetic parameters : accounting for spatial autocorrelation and home range overlap reduces estimates of heritability in wild red deer. Evolution 66:1-16. DOI: 10.5061/dryad.jf04r362. 
402 Villarreal-Espino-Barros OA, Campos-Armendia LE, Castillo-Martínez TA, Plata-Pérez FX, Mendoza403 Martínez GD. 2008. Composición botánica de la dieta del venado temazate rojo (Mazama temama), 404 en la Sierra Nororiental del estado de Puebla. Universidad y Ciencia. Trópico húmedo 24:183-188.

405 Weber M. 2005. Ecology and conservation of sympatric tropical deer populations in the greater Calakmul 406 Region, south-eastern Mexico. D. Phil. Thesis, University of Durham.

407 Weber M. 2008. Un especialista, un generalista y un oportunista: uso de tipos de vegetación por tres 408 especies de venados en Calakmul, Campeche. In: Lorenzo C, Espinoza E, Ortega J eds. Avances en 409

410 el estudio de los mamíferos de México II. México, D. F: Asociación Mexicana de Mastozoología, A.

Yang J, He HS, Shifley SR, Gustafson EJ. 2007. Spatial Patterns of Modern Period Human-Caused Fire Occurrence in the Missouri Ozark Highlands. Forest Science 53:1-15. 


\section{Figure 1}

Geographical location of the San Bartolo Tropical Montane Cloud Forest of the Sierra Madre Oriental in eastern Mexico, where we analyzed the distribution and characteristics of Central American brocket deer resting sites from 2017 to 2019.

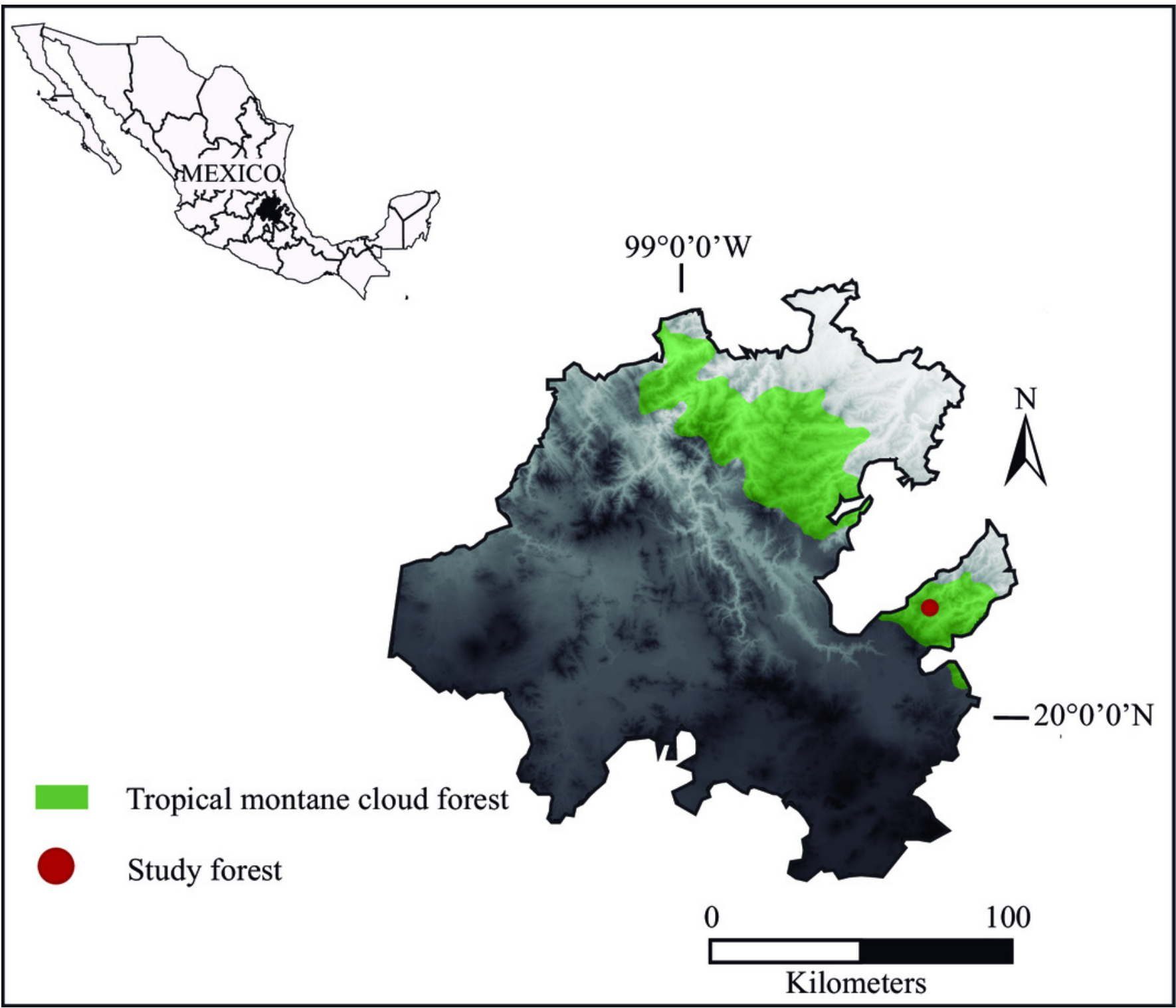




\section{Figure 2}

Location of sampling transects and identified resting sites of Central American brocket deer in San Bartolo, Hidalgo, México 2017-2019.

Transects are illustrated as dot lines while resting sites are represented by white dots

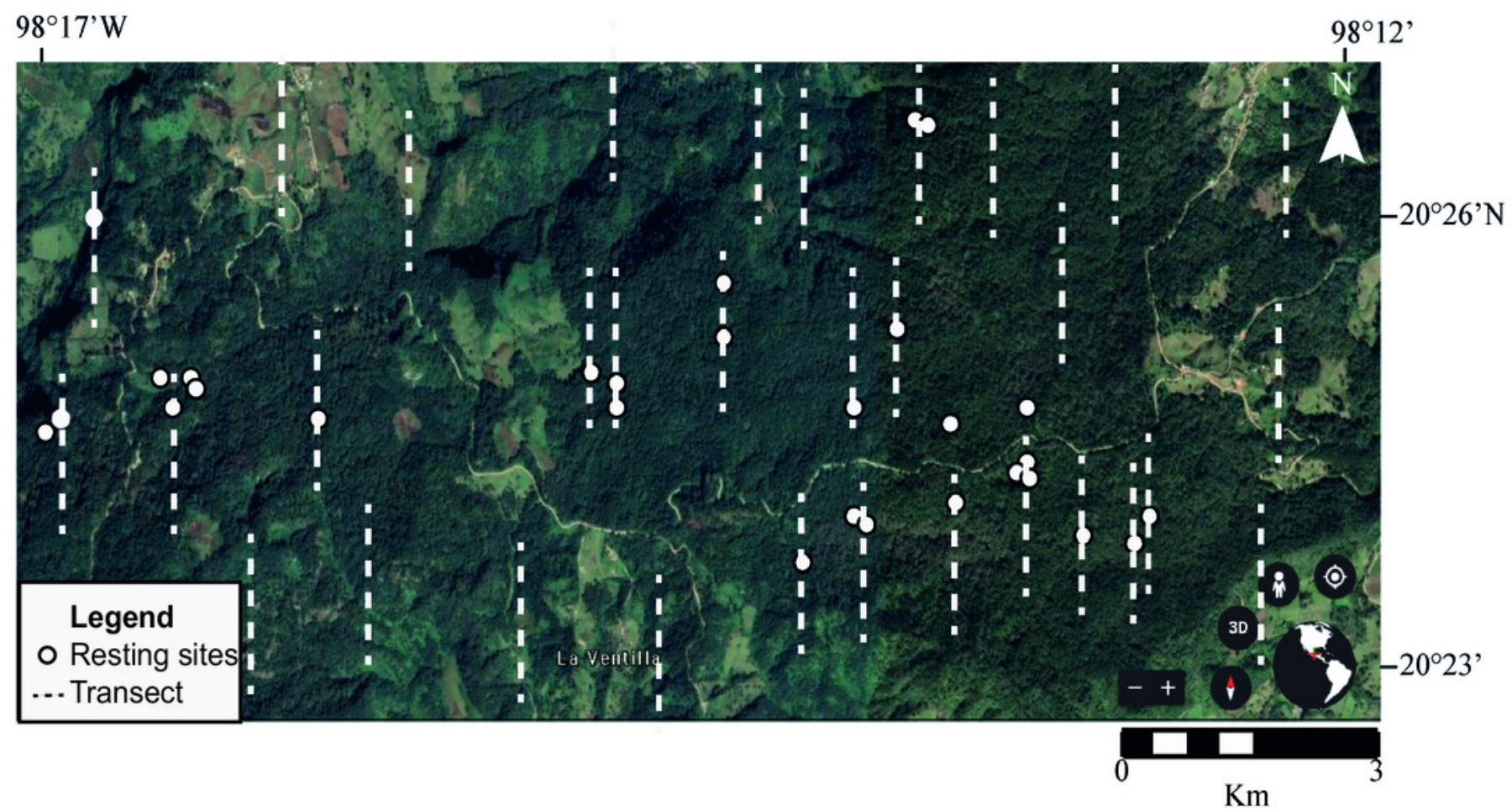


Figure 3

Illustration of the method used to characterize microhabitat of Central American brocket deer in San Bartolo, Hidalgo, México 2017-2019

A) Identification of the resting site, slope from the ground, distance to the nearest water resource and $10 \mathrm{~m}$ transect to each cardinal point. B) Illustration of the method to measure concealment cover for fawns and adults. C) Illustration of the method to measure canopy closure. 


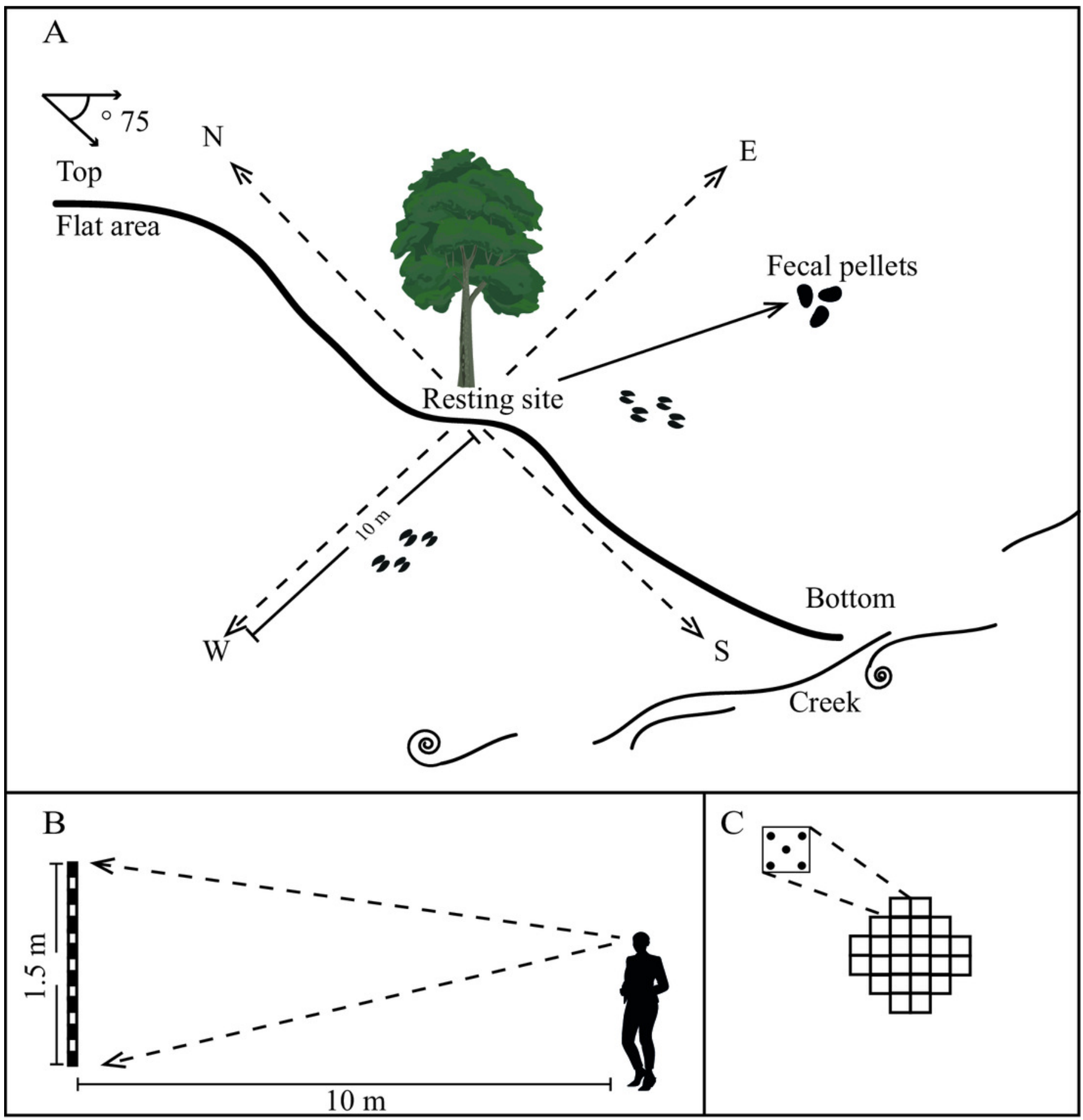




\section{Figure 4}

Representation of the spatial point pattern analysis of Central American brocket deer resting site distribution in San Bartolo, Hidalgo, México 2017-2019

Kernel-smoothed intensity goes from purple to yellow where the function detected an aggregation of resting sites, which are represented with red crosses

\section{$20^{\circ} 27^{\prime} \mathrm{N}-$}

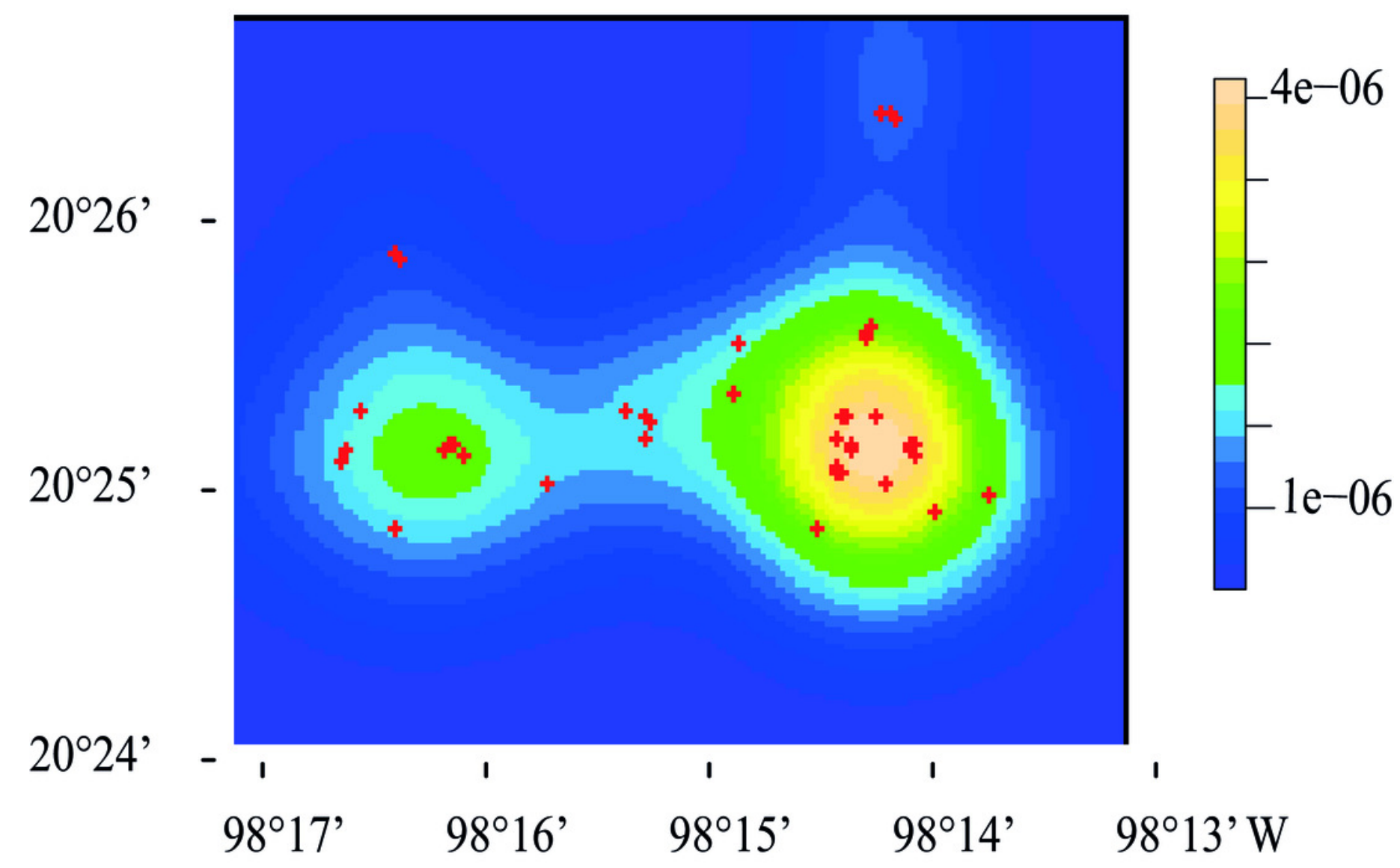




\section{Figure 5}

Generalized $L$ function for the spatial pattern analysis of Central American brocket deer resting site distribution in San Bartolo, Hidalgo, México 2017-2019

The shaded area shows envelopes from 99 simulations of each model, while the solid black line represents the empirical function from the fitted model and the dotted line shows the mean of the function from the fitted model. When the empirical function (solid line) goes above the mean function (red dotted line) means there is an aggregation of resting sites greater than expected by chance 


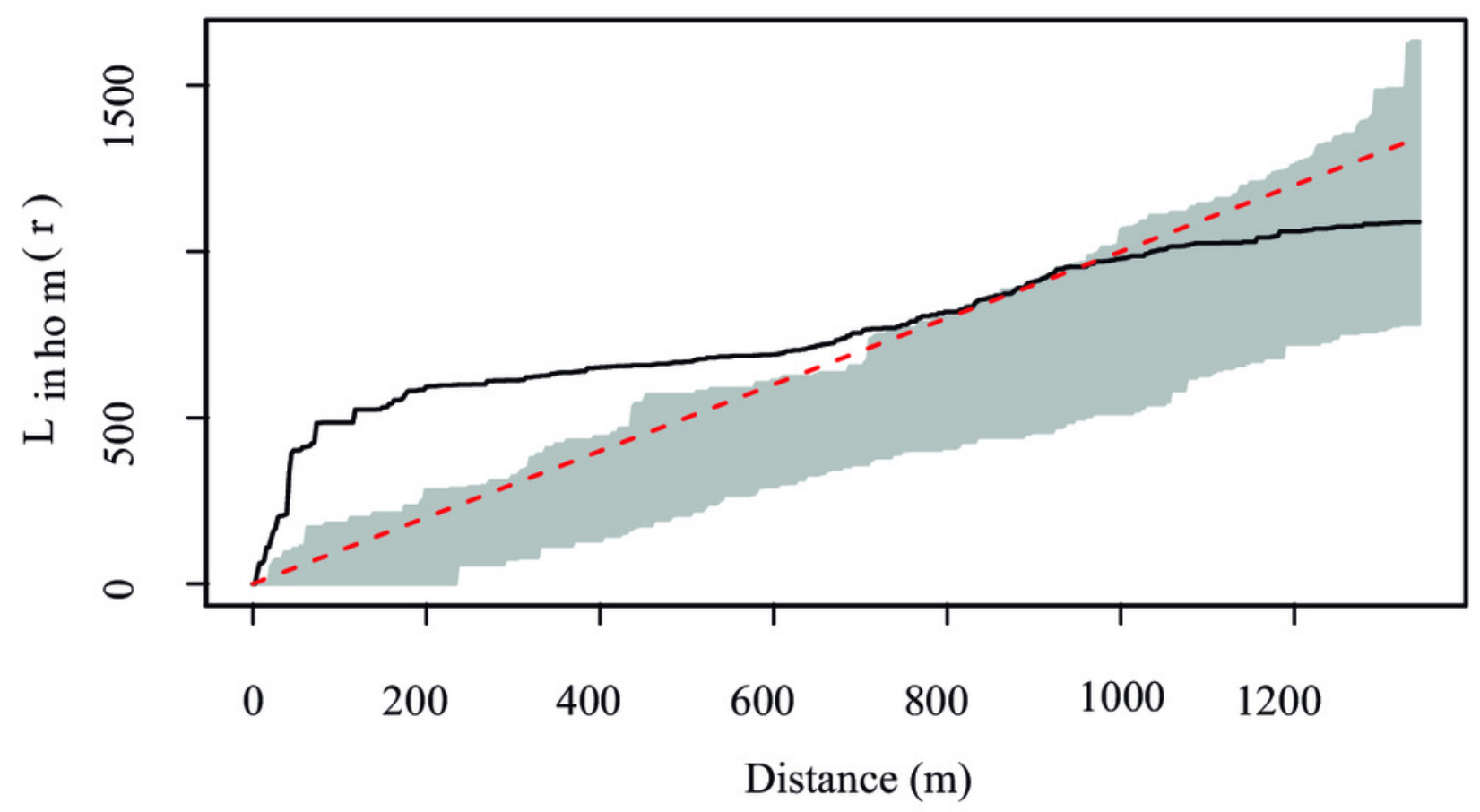




\section{Table 1 (on next page)}

Microhabitat and landscape parameters that were selected to describe resting sites and control plots for the probability of resting sites versus control plots for Central American brocket deer 


\begin{tabular}{lccccc}
\hline Parameter & \multicolumn{2}{c}{ Average } & Estimate & SE & Odds ratio \\
\cline { 1 - 2 } Microhabitat & Resting sites & Control plot & & & \\
\cline { 1 - 2 } Canopy closure (\%) & 98.19 & 68.14 & 0.57 & 8.34 & 1.76 \\
Understory density (ind/m) & 0.50 & 0.52 & -2.95 & 273.84 & 0.05 \\
Understory height (m) & 1.00 & 0.39 & -0.53 & 179.53 & 0.59 \\
Concealment for fawns (\%) & 99.42 & 80.70 & -0.02 & 2.77 & 0.98 \\
Concealment for adults (\%) & 71.31 & 65.16 & 0.01 & 2.64 & 1.01 \\
Escape routes (n) & 4.14 & 2.53 & 0.47 & 44.71 & 1.6 \\
Slope from the ground ( $)$ & 170.58 & 36.49 & 0.31 & 2.29 & 1.37 \\
Scrapes & 0.37 & 0.00 & 1.19 & 121.82 & 3.31 \\
Tree/tree fern DAP (cm) & 91.03 & 30.70 & -0.005 & 0.52 & 0.99 \\
Edible plant species (v.i.a) & 0.89 & 0.71 & 1.19 & 79.34 & 3.29 \\
Distance to water (m) & 32.78 & 131.35 & -0.11 & 0.03 & 0.89
\end{tabular}

\section{Landscape}

Type of biotope

Beech

$\begin{array}{lll}2.55 & 183.9 & 12.86\end{array}$

Oak

$3.64 \quad 177.14 \quad 38.47$

Secondary

$\begin{array}{lll}2.84 & 224.7 & 17.2\end{array}$

Pine

$\begin{array}{lll}-2.36 & 230.17 & 0.09\end{array}$

Rainforest

$0.06 \quad 253.24 \quad 1.06$

Ravines

$\begin{array}{lll}1.53 & 322.73 \quad 4.6\end{array}$

Houses and roads

$\begin{array}{lll}-1.17 & 475.77 \quad 0.31\end{array}$

Grazing

$\begin{array}{lll}-6.52 & 321.22 \quad 0.001\end{array}$


Elevation (m.a.s.1)

Aspect

Slope $(\nabla)$
1846.30

180.39

14.34
1884.4

186.36

26.83
$-0.003$

0.56

0.41

3.37

$-0.006$
0.99

0.99

0.99

1 